\title{
Moeda Seeds: E-Commerce and Crypto Solutions for Development
}

\author{
MoedaSeeds: Comércio Eletrônicoe Soluções Cripto para o Desenvolvimento
}

Discipline: Strategy and Innovation

Subject: Platforms, Social Innovation

Industry: Fintech

Geography: São Paulo/Brazil
Letícia Cristina Kanegae ${ }^{10}$

Adrian Kemmer Cernev ${ }^{1}$ [0

Eduardo Diniz ${ }^{1}$ ()

\section{INTRODUCTION}

In the beginning of 2020, Taynaah Reis, founder and CEO of Moeda Seeds, was caught in an important decision to be taken on an urgent matter. She had to choose in which direction her business would point out a contingency plan to face an unexpected event: the COVID-19 pandemic crisis.

Taynaah Reis is a Brazilian self-taught technologist programmer with hands-on experience in social impact projects, the highlight being her work in partnership with the Brazilian government. In 2017, she decided to put her knowledge into use by building her own social business, called Moeda Seeds, an ecosystem formed by different companies that use blockchain technology to deliver complementary financial services and products. Furthermore, this blockchain-based fintech ecosystem was built at the intersection of two constantly evolving fields: impact

1. Fundação Getulio Vargas, Escola de Administração de Empresas de São Paulo, São Paulo, SP, Brazil.

Cite as: Kanegae, L. C., Cernev, A. K., \& Diniz, E. (2021). Moeda Seeds: E-commerce and crypto solutions for development. Revista de Administração Contemporânea, 25(spe), e200224. https://doi.org/10.1590/1982-7849rac2021200224.en investing and digital currency (cryptocurrencies). Simply put, its main purpose is to empower female microentrepreneurs in economically excluded communities by facilitating their access to microfinancing and supporting them through the entrepreneurial process. This is enabled by Moeda's proprietary cryptocurrencies and its blockchain-based lending platform, a digital platform that uses blockchain to connect anyone around the world who wants to invest in Seed Projects with the entrepreneurs, allowing investors to promptly and transparently invest in Seed Projects meanwhile participating in sustainable growth. Appendix 1 explains blockchain technologies and some business applications. After almost three years since its launch, Taynaah and her co-founders were especially excited for this year's accomplishments. Each year Moeda had grown increasingly, but this year was the turning point for addressing the business' scalability issue.

\begin{tabular}{|c|c|c|c|c|c|c|c|c|c|}
\hline & 1 & 2 & 3 & 4 & 5 & 6 & 7 & 8 & 9 \\
\hline $1^{\text {st }}$ round & $\stackrel{\varphi}{2}$ & $\stackrel{\varphi}{2}$ & & & & & & & \\
\hline $2^{\text {nd }}$ round & $\frac{1}{5}$ & & & & & & & & \\
\hline
\end{tabular}


Notwithstanding the year had just began, a complete rework in the 2020's strategy would be necessary due to the unexpected COVID-19 pandemic crisis. As the quarantine started to become the new normal in most countries and the uncertainty dominated the society, social changes were drastically accelerated, demanding an agile adaptation more than ever before. With priorities shifting completely, Taynaah was preparing herself to guide Moeda Seeds with a new strategic planning. The challenges that came with the external context were definitely not easy, but a strong response had to be designed and communicated really soon.

The goal was clear: to guarantee Moeda's survival throughout the crisis without leaving the entrepreneurs hanging out to dry. Thus, Moeda had to rework its commercialization strategy to support its transition to online sales. However, the real dilemma was: What is the best way to do it? How could Moeda support entrepreneurs' adaptation to online sales while still managing its own survival?

\section{THE ENTREPRENEUR}

Taynaah Reis, the CEO of Moeda, is a Brazilian entrepreneur closely linked to technology and social impact since she was a child. She became a self-taught technologist programmer by applying her skills to build her own tech projects related to several fields such as design, education, philanthropy, agriculture, urban planning, and music. In 2010, her skills were recognized by the former Brazilian president, Dilma Rousseff, when she built a social network for agricultural farm families, called Rede Brasil Rural. By making the connection through the platform, the farmers could sell their products directly to public schools, bringing efficiency to the chain and instantaneous impact.

Her path was also influenced by her family's background, especially of her father, Luiz Antonio Gonçalves dos Reis. He had been involved in the environmental field and rural communities support, working in association with local authorities, cooperatives, and rural producers' associations. For almost a quarter century, he had been working for the Brazilian Ministry of Agriculture, with special highlight to his work at the Rio de Janeiro Earth Summit in 1992 (ECO-92) and his support for youth training programs in the agricultural sciences area. In 1999, he founded the New Frontiers of Cooperation Institute (INFC), after broadened his work to include support for small family farmers, in partnership with UNDP (United Nations Development Program). The INFC team has already successfully executed over 1,500 projects that directly affected the lives of over three million families in urban and rural areas since its foundation.
With UNDP as one of the main sponsors of INFC projects, Taynaah got the opportunity to work for the United Nations' sustainability team when she was 28 years old (Figure A1), which also opened the doors for her to live in Sweden, Singapore, United Kingdom, and New York. While in the UN's headquarters, she began to study blockchain and cryptocurrencies and their potential applications. At the end of 2016, while sketching Moeda's business model, Taynaah had the idea to organize a hackathon to help her generate business ideas and product concepts.

In March 2017, during the 4th Edition of The Impact Leadership 21's Annual Power of Collaboration Global Summit at the United Nations, Taynaah made a speech about how to achieve the SDGs and change the world, by bringing people together and using technology to enable social transformation. That year's theme was "The Impact of Convergence 2.0: Leveraging Technology, Investment and Philanthropy for Sustainable Development Goals (SDGs)," the collection of 17 sustainable development goals designed by $\mathrm{UN}$ to be a blueprint to achieve a better and more sustainable future for all by 2030 . While sharing her vision of a better future, Taynaah also inspired the audience to do their part, leaving them with a question to reflect: "How can I do impact? How can I do my part to contribute to those goals?" Later that day, Taynaah was invited to host one of the hackathons sponsored by UN. She did not know yet, but that would become the day one for Moeda Seeds.

\section{WALKING THROUGH THE TIMELINE}

A month after the hackathon, the first version of the Moeda's App was launched in April 2017, along with pilot projects that build the foundation of Moeda's expansion. A couple of months later, Moeda opened a holding in Uruguay, becoming the first blockchain company in a Free Trade Zone. Its location choice was due to the market maturity for blockchain technology and proximity to Brazil, where the operation would take place.

In August 2017, the founders decided to launch Moeda's Initial Coin Offering (ICO), an innovative approach for raising funds directly from the public through the use of cryptocurrencies, which became the source to Moeda's continued expansion. The main blockchain technologies and business applications are described in Appendix 1. Such strategy is often used in cryptocurrency projects - blockchain-based product, service, or platform - that still need to be fully developed. In two weeks, $19,628,888$ MDA tokens (Moeda's only token that can be traded in the open market) were issued, each one worth US\$ 1.00, becoming the biggest Brazilian ICO, which still remains. People all over the world bought those tokens. 
With those funds, it was feasible to put the business into good order, improve the app platform, build fundamental partnerships, and fund the first round of Seed Projects in rural Brazil.

In September 2017, Taynaah Reis joined the Parliamentary Special Committee on the legislation of virtual currency to define the future of cryptocurrency in Brazil and the Brazilian Central Bank acknowledged Moeda's business model on a live national broadcast. Additionally, in that same month, MDA cryptotoken landed on the Binance list, which means Moeda passed certain thresholds for financial and regulatory viability in addition to a degree of trust from Binance, one of the most popular cryptocurrency exchanges.

In November 2017, Moeda launched at the UN COP 23 Initiative in Blockchain on Climate Change the blockchain responsible to monitor and measure its projects' commitments to the SDGs. As already mentioned, Moeda wanted to go beyond offering simple and pure credit; it aimed to leave a real and long-lasting impact, which is why UN's SDGs were always Moeda's main guideline, from minor everyday actions to which Seed Projects were going to be supported. This means that every impact investment Moeda launches must contribute to the implementation of the Agenda 2030 goals and a key practice to achieving it is measurement. Therefore, during the Moeda Seed Acceleration Program, which all entrepreneurs had to go through, a collective action plan needs to be structured between Moeda's staff and the entrepreneurs with the methodological path to reach the SDGs through on-site and remote technical monitoring. This process was also done with blockchain technology, which provided transparency to investors and trust that the records could not be changed. In January 2018, Moeda Seeds announced the implementation of its first round of financing. In total, 18 projects were embraced, all of them fulfilling at least one of the UN's SDGs and having direct impact in local economies.

In June 2018, the Audit Log of Moeda Blockchain Projects was implemented in the IBM Hyperledger fabric composer, allowing Seed Projects to be monitored with full transparency.

In September 2018, the second cryptocurrency, or more specifically, a flat pegged token called MDABRL, was deployed to be used on Moeda's ecosystem. Tied 1:1 to the Brazilian Real, it was designed as a stable coin, minimizing the price volatility of MDA relatively to the Brazilian fiat currency, where the operation was taking place.

In January 2019, token MDA Loyal was launched together with Moeda's Loyalty Program and, like MDABRL, it cannot be traded on open market. As the name suggests, this is a digital currency created to reward investors who are 'loyal' to Moeda's project and can be used by the business in different contexts. First, it can incentive investors to keep their MDA earnings in Moeda Wallet by rewarding with MDA Loyal. In addition, it can be used in marketing campaigns as a gift for people with interest in supporting Moeda's projects, motivating more people to invest in Seed Projects.

In February 2019, the fourth token released by Moeda Seeds was MDAX, created especially for MoedaGo!, a digital game created to foster a Financial Education Program within the ecosystem. The more people play, the more impact is distributed, since all points scored in the game are worth MDAX that can be used to invest in Seed Projects. Each MDAX corresponds to 0.01 MDABRL.

In July 2019, Moeda released Moeda Pay, its own digital account and wallet to the general public, launched in partnership with the MasterCard flag.

In September 2019, Moeda started developing its own Receivables Investment Fund (FDIC, in Portuguese).

Almost three years after Moeda's launching, it achieved over 200 implemented projects that collectively worth five million Brazilian reais. Currently, Moeda's investment portfolio is constituted by more than 5,000 investors and over 80 employees are responsible to support the fintech ecosystem and make sure the investments are distributing impact. For 2020, the plan was already been built and put in place to keep up with the business accelerated growth. Notwithstanding, the crisis coming ahead could not have been predicted, demanding a quick and sharp adaptation for the following months.

\section{THE BUSINESS}

The hackathon's challenge came up with new ways to increase financial support for blockchain technology solutions embodying the SDGs. As financial inclusion and gender inequality were the two SDGs targeted in the hackathon, Taynaah highlighted the tough reality faced by women microentrepreneurs in economically excluded communities. For Taynaah, the main problems to be tackled were the following:

\section{(A) Insufficient access to capital}

According to the World Bank, almost 35\% of the world's population has no banking account, however, when it comes to active bank accounts this number raises to almost $50 \%$. This means that almost half of the entire population is excluded from the financial system, being highly associated to poor and socially excluded communities.

Thus, it proves that the lack of infrastructure and financial education increases marginalization disadvantages. 
Another barrier is the difficulty for taking loans at fare rates and with proper orientation to optimize resource application. Besides inefficiency and bureaucracy from both public and private sectors, a key factor that influences in this barrier is investors' lack of trust in providing capital to those economically excluded. As a result, this problem of trust turns into a higher risk perception and consequently, higher fare rates. Therefore, the lack of a transparent, reliable, and updated accountability needed to be addressed.

(B) Gender bias in investments

Women have an additional disadvantage: a gender bias from investors. When it comes to put money in projects led by women, investors show less interest on investing. Historical factors such as a male dominance over the family's income, making women not being paid for their domestic work, are in the roots of this gender discrimination. Consequently, women have less access to capital and to the financial system, and correlatively it is less common for them to lead companies, since they have more barriers to start, operate, and expand their business.

(C) Lack of entrepreneurial and commercialization skills

The third barrier was the absence of proper management and technical knowledge. Due to reduced accessibility to education, the risks involving business decision-making were higher, increasing the chances of bankruptcy.

Eventually, the hackathon's winning team submitted the basic concept behind Moeda and later became Taynaah's cofounders of Moeda: Isa Yu, a recent graduated in Mathematics from Penn State University, and Brad Chun, a venture capital investor with expertise in blockchain and cryptocurrency.

\section{Moeda's purpose and believes}

Moeda was built on the foundations of the United Nations, embodying the belief of changing the world through the achievement of the 17 SDGs, in particular financial inclusion and gender equality. Aiming for a fairer world, its main purpose is to empower female microentrepreneurs in economically excluded communities by facilitating their access to financing and providing them with technical and management support. By promoting sustainable growth and development on the long run for those marginalized communities, Moeda humanizes finance and contributes to create social impact.

\section{Moeda's way of doing it}

Moeda builds trust between its stakeholders with a blockchain-based fintech ecosystem, which allows anyone to invest in projects with social impact while improves investors' awareness of the results of their investments. To make it work, Moeda relies on three key-factors. First, it ensures security by using blockchain technology, what makes the history of any digital asset unalterable and transparent using cryptography and distributed transaction records. This assures data immutability and traceability in a transparent way to all Moeda's transactions, along with secure financial transactions $24 \times 7$. Second, it improves the success rate of investments by providing management and technical support to microentrepreneurs and other players along their chains. Third, it gives accountability through a weekly report done by Moeda containing all management actions, enhancing investors' perception by keeping them constantly in the loop.

Moeda Seeds have also innovated by developing a system based on more than one cryptocurrency. MDA token was the first one launched and currently the only one that can be traded in the open market and it is the main tool to invest in Seed Projects. However, other tokens were already launched to support the ecosystem. A great example is MDABRL, a cryptotoken paired with the Brazilian real and designed to keep it simple for entrepreneurs who do not have financial education to manage the typical volatility of the cryptocurrency market.

Lastly, it is important to highlight that the entire process only holds up because Moeda Seeds is financially selfsufficient. Thus, Moeda's approach covers environmental, social, and financial dimensions of the triple bottom line sustainable business strategy.

\section{Moeda's business model}

Moeda works as a credit union system powered by blockchain technology that operates in the entire social business chain, from financing to production to distribution of results. Moeda's ecosystem developed the following products and services:

\section{(A) Moeda Seeds' Web Platform}

It was designed with two portals, one for investors and one for entrepreneurs, each one to deliver the appropriate features and services to support their different needs (Figure A2).

\section{(B) Moeda Seeds' Mobile App}

It increases mobility and accessibility to services, allowing users to have easier and quicker access to their Moeda account and digital wallet to make instant peer-topeer payments (Figure A3). Beyond that, it serves as source 
of information for Moeda to understand the stakeholders' behavior and design improvements accordingly.

\section{(C) Moeda's services for investors}

Investing with Moeda Seeds ecosystem means participating in the impact generated by each Seed Project, helping fight poverty, inequality, and climate threats while promoting local development, sustainable growth, and women's empowerment. Moeda's services foster trust by relying on transparent accountability. By boosting the investors with relevant information about Seed Projects and analysis tools, Moeda's ecosystem assists the investment decision-making process and monitoring.

\section{(D) Moeda's services for entrepreneurs}

Receiving investments from Moeda means to the entrepreneur more than seeking financial returns. Moeda's Impact Formula is a logic model that measures Seed Projects financial and extra-financial returns. Based on four key performance indicators (KPIs) — wisdom, cooperation, trust, and environment - , it quantifies social economic impact and ability to thrive autonomously. Moeda's core services provided to entrepreneurs go beyond access to funding by providing business education, network of suppliers and contacts, simplified digital accounts, and electronic means of payment besides other financial products.

How does it work? First, entrepreneurs interested in the program fulfill an application form to show their interest. Then Moeda proceeds to an evaluation process to select the microentrepreneurs and projects able to receive funding by considering traditional and nontraditional credit history factors, enhancing female led projects that intend to create social impact on the local community (Figures A4, A5, A6). Once selected, entrepreneurs receive Moeda's management and technical support, along with capital investment.

During Moeda Seed Acceleration Program, entrepreneurs learn how to make feasibility studies, to build a solid business plan, and to assemble a minimal viable product (MVP). By using the MVP's methodology, the goal is to quickly launch a prototype, beginning the learning process as fast as possible to make adjustments. The funding is also tie-in to this process, since the entrepreneurs receive the capital in parts, as the project succeeds and needs to expand. To increase chances of maintaining the business on the long term and guaranteeing its sustainable impact, Moeda strongly invests on the entrepreneur's education, caring out for the entire chain, aiming to improve efficiency and optimizing business activities. This is always done with a renowned partner in the field, usually the organization with most knowledge and practical experience. Throughout the entire process, all transactions are done by Moeda Pay, which allows Moeda to track each cent impact to the communities along the chain. Besides supporting the Seed Projects' accountability, access to this data helps increasing investors' trust.

\section{THE BLOCKCHAIN TECHNOLOGY BEHIND MOEDA'S ECOSYSTEM}

There are three key blockchains that support Moeda's business model in different ways that complement each other: (a) a main cryptotoken as tool of investment, (b) a blockchain that assures traceability of all transactions involving Moeda's stakeholders, and (c) a stablecoin tied to the country's fiat currency where the operation takes place that simplifies the complexity of Moeda's business model to its stakeholders.

Moeda's main tool of investment is the MDA cryptotoken, which people all over the world can buy to invest on Seed Projects. It is the only one that can be traded in the open market and there are currently 19,628,888 MDA tokens available, all of them created with Moeda's Initial Coin Offering (ICO) that raised almost \$20 million dollars. Part of those funds became the source to finance the Seed Projects supported by Moeda and the remaining amount functions as a cushion that supports the business model as a reserve fund.

The second blockchain aims to support Seed Projects' accountability and shows how each cent is affecting society. By assuring data immutability and traceability of all the transactions made involving any Seed Project, it allows fully transparent monitoring that backs investors' trust. In addition, it enables Moeda to maximize its impact (Figure A7).

In a third blockchain, a stablecoin called MDABRL is pegged 1:1 to the Brazilian real, since the operation takes place in Brazil. It manages to bring stability to the ecosystem that is not possible due to MDA's high volatility. In practice, it helps Moeda secure the money directed to each project, since the system automatically converts each investment made in MDA into MDABRL and it also allows investors to monitor assets received as bonus at the end of each investment period, in case they want. If not, they can choose between investing in another Seed Project and converting it into MDA. In addition, it has the purpose of bringing Moeda's stakeholders closer to the reality of the female entrepreneurs who lead the Seed Projects, and do not have skills to manage the typical volatility of cryptocurrencies.

Besides these three main blockchains, Moeda also released other cryptotokens based on perceived demands and opportunities. 


\section{COVID-19 CONTEXT}

Emerged in December 2019 in Wuhan, China, the illness is caused by coronavirus 2 (SARS-CoV-2), with severe acute respiratory syndrome symptoms. Despite the lack of knowledge about the illness, its alarming threat is related to the risks involving the higher rates of spread, severity, and lethality (especially for the elderly) in comparison to a common flu. On March 11, the World Health Organization (WHO) upgraded the status of the COVID-19 outbreak from epidemic to pandemic. Declaring a pandemic was not related to changes in the disease's characteristics, but to its geographical spread. In other words, its spread had gone beyond expectations and became a worldwide phenomenon. As a result, most countries adopt strict measures of social isolation to hold spreading and avoid overloading the health system capacity. Cities became desert as people stay indoors, either by choice or government mandatory measures. Frontiers were shut down, entire industries prohibited to function, and public places stayed closed all over the world.

With the quarantine becoming the new normal for a huge part of the population, many changes came as consequence. Companies trying to adapt to digital, people losing jobs and income, not knowing when normality will return and which scars will be left in the society. The uncertainty that is accelerating changes and disrupting the world as we knew shows that agility is required now more than ever before. Although COVID-19 started as a health crisis, it is much more than that, since it has the potential to turn into a devastating social, economic, and political crisis that can leave much deeper scars. Was it just the begging?

The uncertainty overcame all spheres and the only conviction is that priorities shifted completely, demanding a thorough strategy reengineering. Overnight, in-person sales became unfeasible, either because people would not want to leave their homes or because public representatives have declared lockdown. Businesses were quickly trying to migrate to online sales and Seed Projects needed to do the same. In addition, they could not rely on their biggest buyers, since they were abroad and many countries were closing their frontiers until further notice, turning exportation into another risk for the entrepreneurs. Furthermore, almost instantaneously since the crisis hit Brazil, there was a shift down in non-essentials' sales, whereas there was a relevant growth in the essentials' categories. Between the Seed Projects categories, artisanal fashion items would be the most affected ones, while food and beverages would be the most benefited ones. In all cases, but especially if the focus shifted to perishable items, new hygiene procedures would be required. Definitely, there were many variables to be thought of, but the key point was how could Moeda rework the commercialization strategy to support the entrepreneurs to migrate to online local sales without increasing the risk to a point it jeopardizes Moeda itself in such a sensitive period.

\section{ALTERNATIVES SEARCH}

Before taking a decision, Taynaah talked to Moeda's main stakeholders and gathered her team to come up with different alternatives. The goal was clear: guarantee Moeda's survival throughout the crisis without leaving the entrepreneurs hanging out to dry. But the real question was: What is the best way to do it? How could Moeda support entrepreneurs' adaptation to online sales while still managing its own survival?

One of the options Moeda had at its disposal was a lab experiment put into test in late 2019: its own marketplace, an online platform where any entrepreneur could sell his goods. Although it is still in beta version, it could be an alternative to be accelerated in 2020 to expand the fintech ecosystem's business while supporting Seed Projects in this transition. However, starting it is undoubtedly tough, since it would require Moeda to foster the market on both sides, sellers and buyers. Besides, there is not one single type of marketplace business model, so if Moeda decided to point out into this direction, it should evaluate more important variables, such as if it would take care of the storage and shipment or each entrepreneur would be responsible for managing his own products and delivering to the final customer.

Taynaah also remembered a chat she had a couple of weeks before with an e-commerce specialist, who described the different digital e-commerce models and players in Brazil.

As following, there were five major alternatives to be carefully evaluated. Even though two or more approaches could be combined, one clear path had to be chosen between them.

\section{(A) Supporting each one of Seed Projects separately}

Remain with the first-party relationship (1P), which means each Seed Project would keep performing as supplier and retailer. Moeda's role would still be giving management and technical support, but now with a special focus on online commercialization, such as teaching each one how to create an e-commerce. 


\section{(B) Accelerate its own marketplace with the fulfillment storage and delivery}

Invest in Moeda's own online marketplace expansion with fulfillment option, maintaining marketing and sales responsibilities with the entrepreneurs, who would have partial control over their products. Moeda would display the items in its own marketplace together with other Seed Projects, meaning that they would be selling through Moeda's marketplace, which could charge a fee for their sales as other marketplaces do. In this scenario, Moeda would also be responsible for the storage and shipment of the goods sold to the final costumers, which would require it to quickly develop logistics expertise.

\section{(C) Accelerate Moeda's own}

\section{marketplace but keeping storage and} delivery as Seed Projects' responsibility

Invest on Moeda's own online marketplace expansion but without fulfillment option, maintaining marketing, sales, storage, and shipment responsibilities with the entrepreneurs. This means they would have total ownership and control over their products and Moeda would only display them in their own marketplace, together with other Seed Projects. Like alternative B, they would be selling through Moeda's marketplace, which could charge a fee (lower than in alternative B) for their sales.

\section{(D) Sell on a third-party marketplace in Brazil}

Establish a strong partnership with an already consolidated marketplace in Brazil. Since Brazilian's marketplace context is highly concentrated, putting Seed Projects in an already consolidated marketplace would make it to benefit from high value on the buyer's side. However, none of them had food and beverages expertise, being a barrier if they decide to focus on them. Between the major players, the best match would be Mercado Livre, due to its easier acceptance of microentrepreneurs and longtime investment in the long tail type of sales. Although it does not have the expertise on selling perishable items, it just began a trial of selling nonperishable food and beverages.

\section{(E) Create a new cryptotoken}

Launch a new cryptotoken with the main purpose of stimulating people to buy products supported by Moeda via online sales. This new token would work as a cash back for first purchases: buyers would get back a percentage of the total amount spent into this new token, which could be used in their next purchase, stimulating their return in order to use the gifted coupon.

\section{TIME TO MAKE HARD DECISIONS}

Taynaah was facing a tough decision-making. All alternatives had its pros and cons with opportunities and risks attached to them. Although some alternatives could even be combined, a clear pathway to go through the crisis had to be indicated and communicated to the main stakeholders, since the entire business was based on reliability. In addition, due to Moeda's streamline team, it is important to have a clear work front as priority so the team could focus their efforts on it. 


\section{APPENDIX A. Blockchain technologies and business applications}

Blockchain is a revolutionary way to store and preserve data, which allows trust, transparency, rastreability, and immutability of information. Based on cryptography, distributed ledger, and a consensus protocol, information is recorded in blocks, such as pages of a book, which are concatenated with cryptographic hashes. Once the ledger is confirmed by the majority of network participants, that valid version of the ledger is replicated and distributed to the entire network, which may be public, private, or permissioned.

Blockchain platforms are, in fact, extensive distributed networks of computers (without a central server), operating with the same blockchain protocol, on which various assets and services can be built, such as cryptocurrencies and tokens, financial services, tracking and information systems, and government and value chain records.

Some fintech use blockchain platforms to offer financial services that require the attributes commonly found in blockchain networks, such as transparency, rastreability, and immutability of information, thereby seeking to build the trust of their stakeholders.

Digital currencies are currencies that only exist in electronic form. They are usually composed of a central system, responsible for data and platform management, and a mobile app for conducting transactions and money exchanges. With a different architecture, some digital currencies are built on blockchain platforms, without a central management or control, being then called cryptocurrencies.

Cryptocurrencies are those digital currencies created with blockchain technologies, which generally seek to distribute control over the platform. Although there is no master control, its governance can be opened or closed. Examples of cryptocurrencies are Bitcoin, Etherium (Ether), Ripple, and Moeda.

Cryptotokens usually represent an asset or utility, being categorized into three types: currency tokens, utility tokens, and investment/asset tokens. Examples of cryptotokens are ABC and BNDES Token (issued by the Brazilian National Bank for Economic and Social Development).

Finally, ICO stands for Initial Coin Offering, an emergent type of business financing based on the issuance of cryptoassets, either currencies or tokens 


\section{ANNEX A}

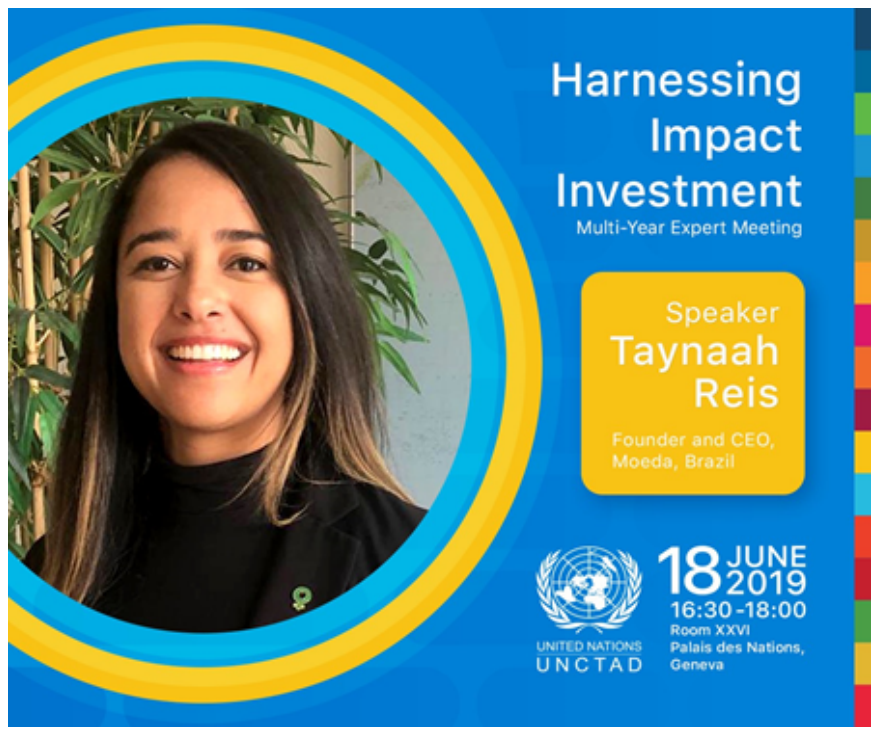

Figure A1. Taynaah Reis, Moeda's founder and CEO.

Source: Retrieved from https://moedaseeds.com/ on August 23, 2020.

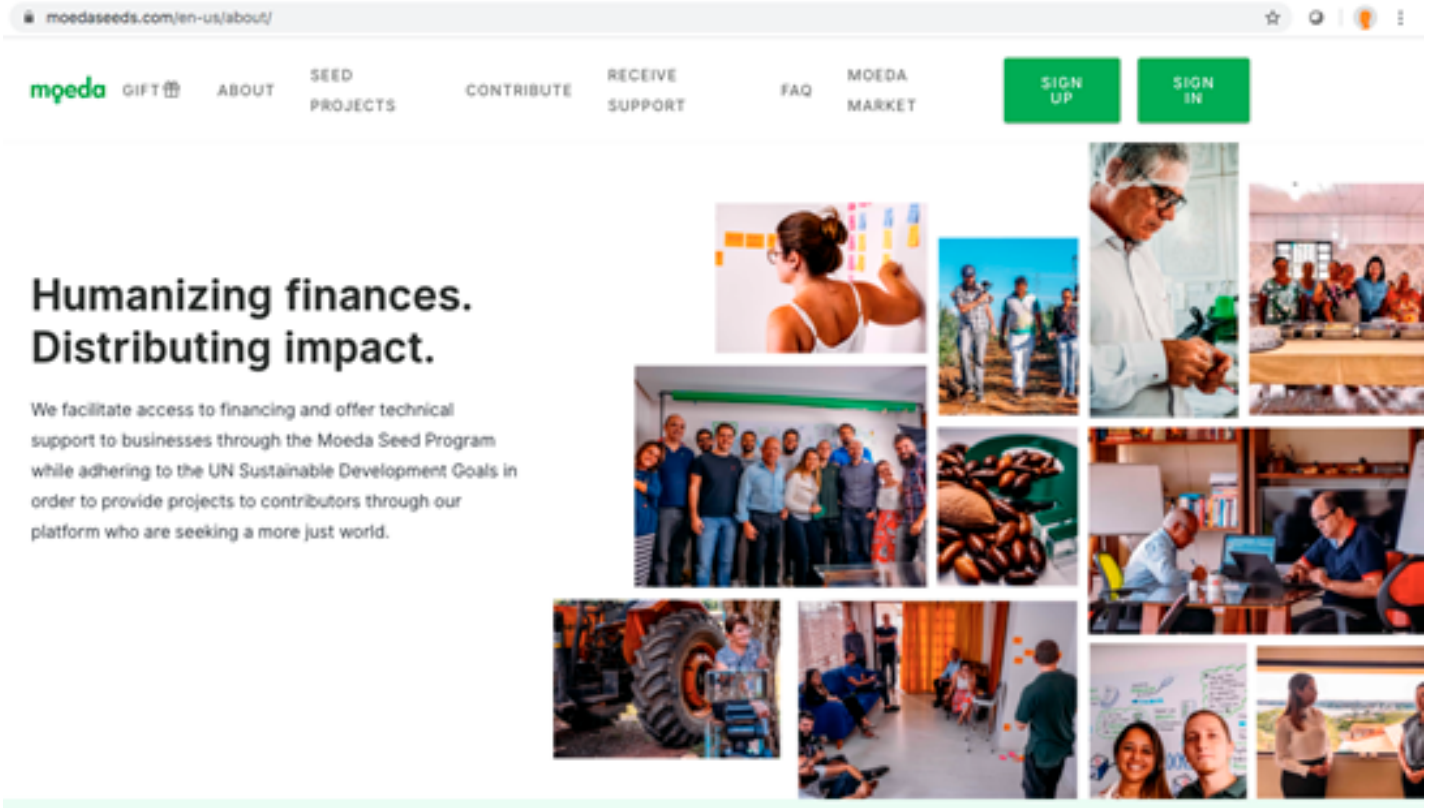

Figure A2a. Moeda Seeds' web platform.

Source: Retrieved from https://moedaseeds.com/ on August 23, 2020. 


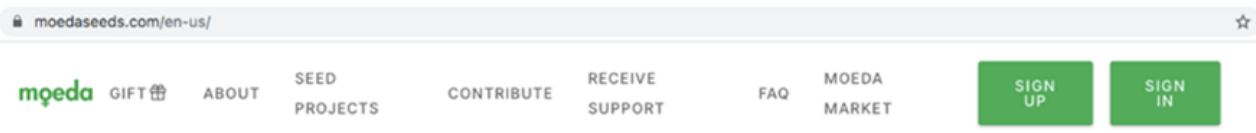

\section{Support our Seed Projects}

Find out more about the projects selected by Moeda Seed Program, learn how do they make an impact and contribute towards achieving the UN Sustainable Development Goals. Support and keep

track of their progress. This is where you get to distribute impact and create a more sustainable

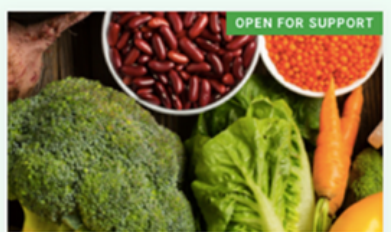

SUPPORT THIS PROJECT

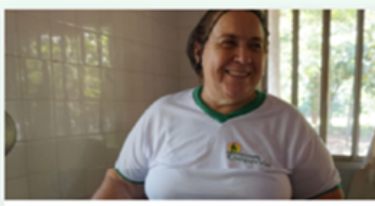

Cooperval Craft Beer

SEE PROJECT DETAILS

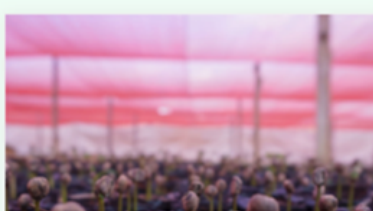

Seed Project: Sustainable Coffee

SEE PROJECT DETAILS

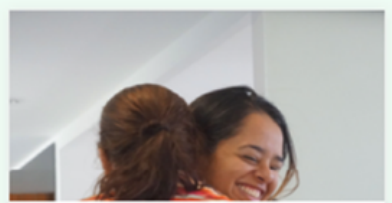

Cooperval Craft Beer Fase 2

SEE PROJECT DETAIL:

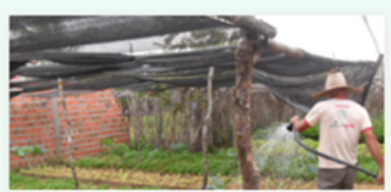

Women doing business in the Sertăo (hinterland)

SEE PROJECT DETAILS

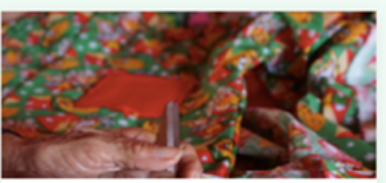

COOPEREDE: Community Production

SEE PROJECT DETAILS

Figure A2b. Moeda Seeds' web platform.

Source: Retrieved from https://moedaseeds.com/ on August 23, 2020.

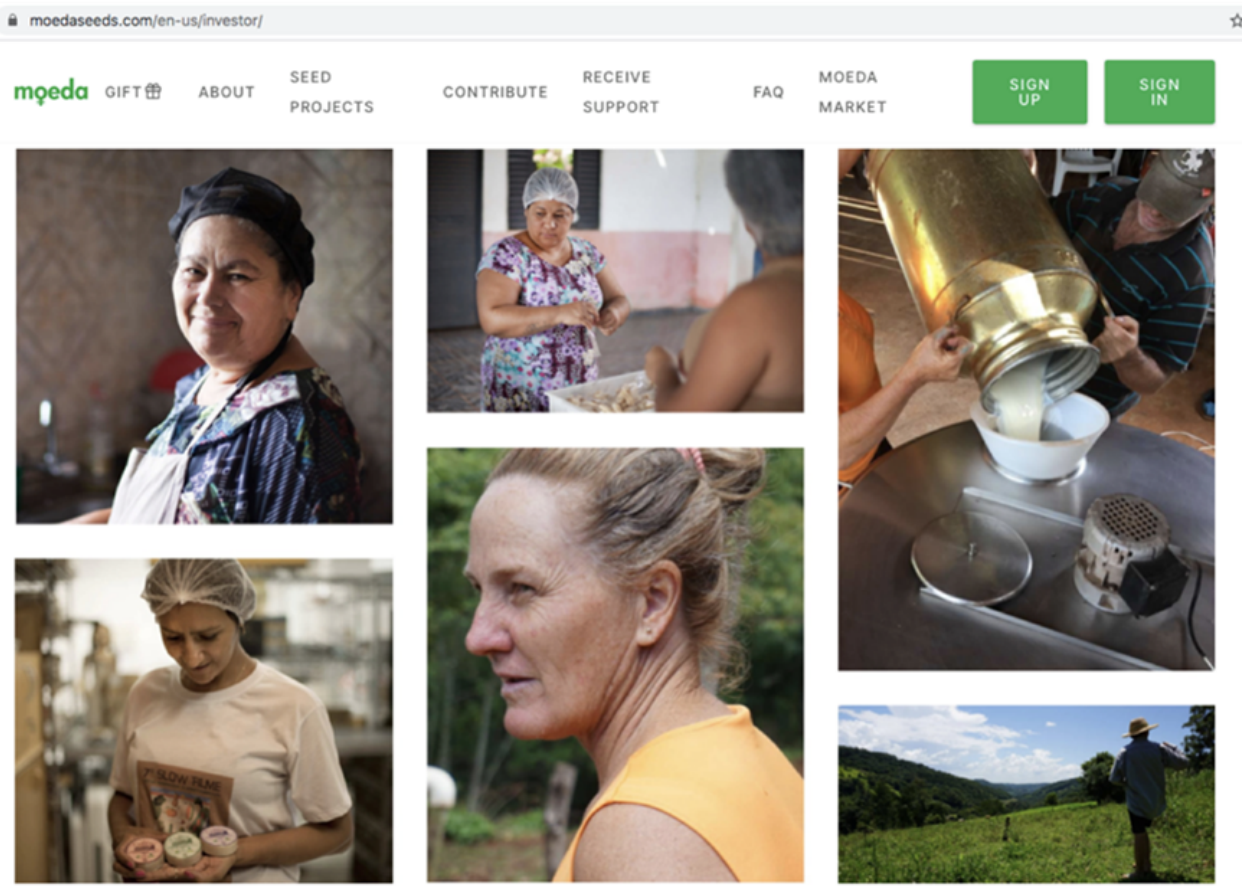

Figure A2c. Moeda Seeds' web platform.

Source: Retrieved from https://moedaseeds.com/ on August 23, 2020. 

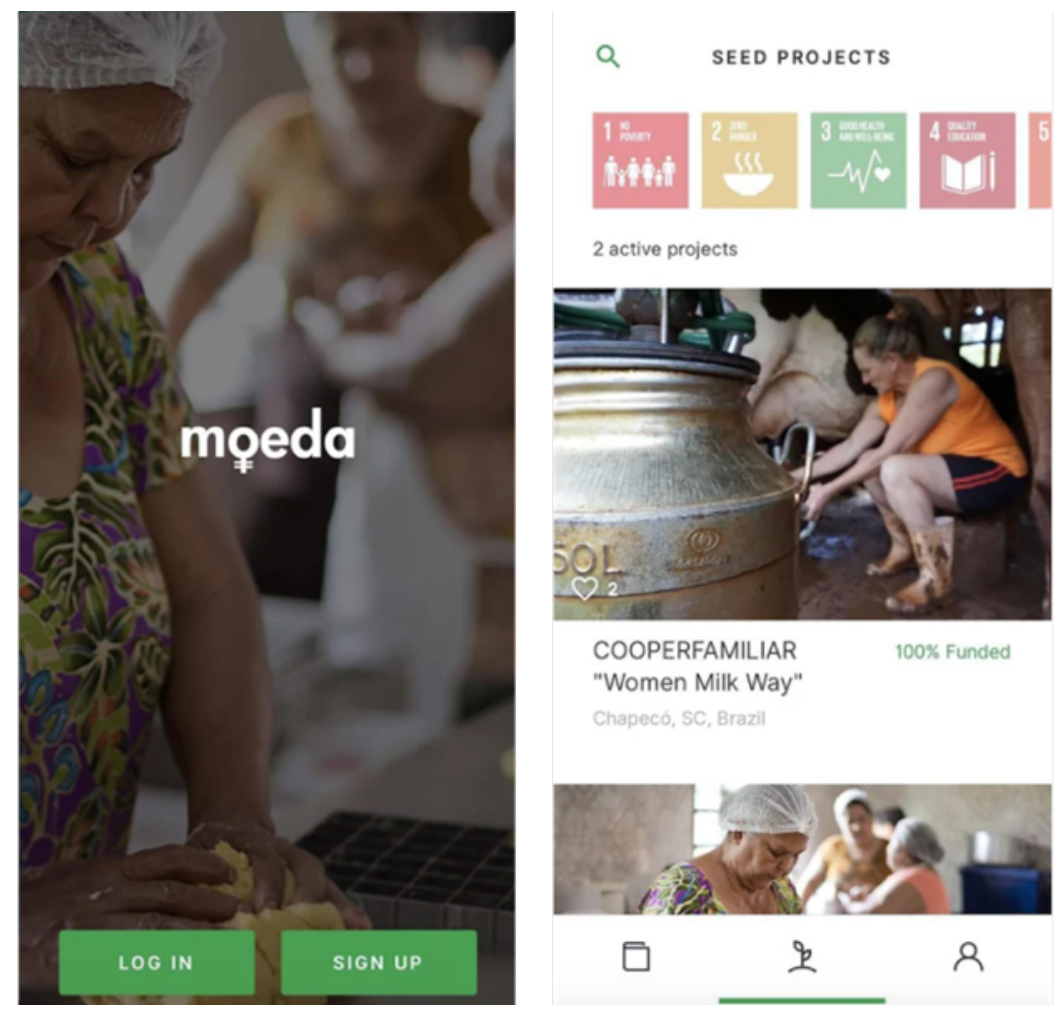

$$
\begin{aligned}
& \text { COOPERFAMILIAR } \quad \text { 100\% Funded } \\
& \text { "Women Milk Way" }
\end{aligned}
$$

Chapecó, SC, Brazil

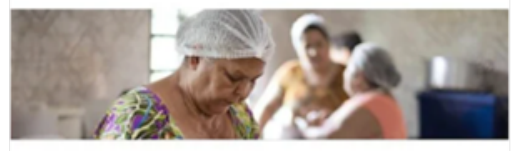

$\square$

2

R

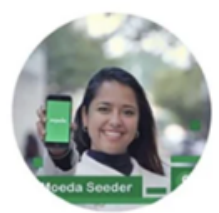

Taynaah R.

Proud of you Moeda team !

My Details

$>$

About Moeda

Sign out $\rightarrow$

\section{Favorite Seed Projects}

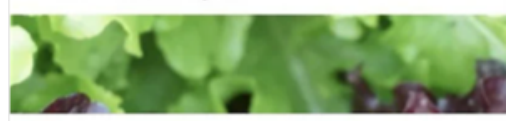

ㄴ. 2

R

Figure A3. Moeda Seeds' mobile app.

Source: Retrieved from https://play.google.com/store/apps/details?id=in.moeda.app\&hl=pt_BR on August 23, 2020.

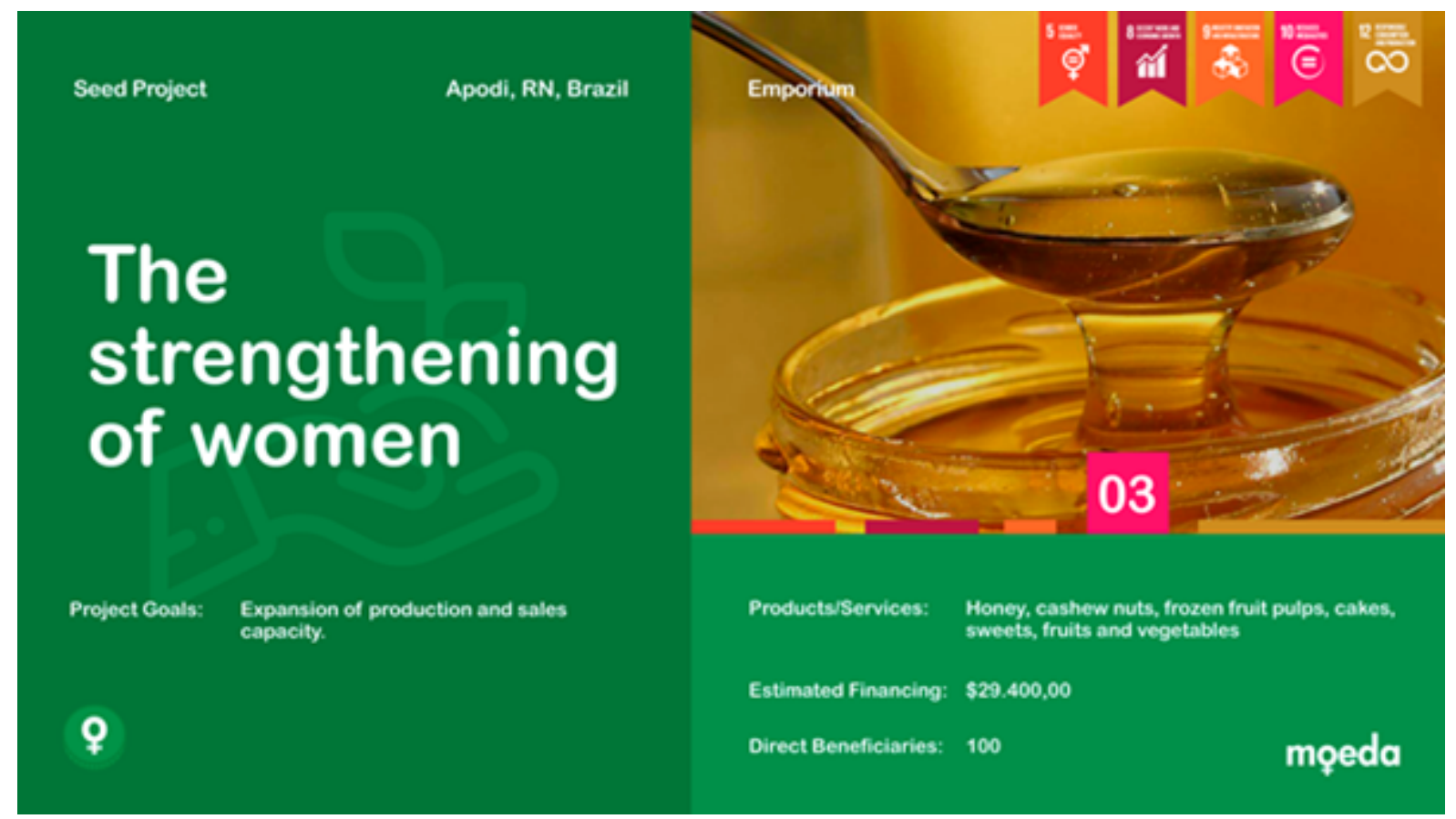

Figure A4. Example of Seed project.

Source: Retrieved from https://moedaseeds.com/ on August 23, 2020. 


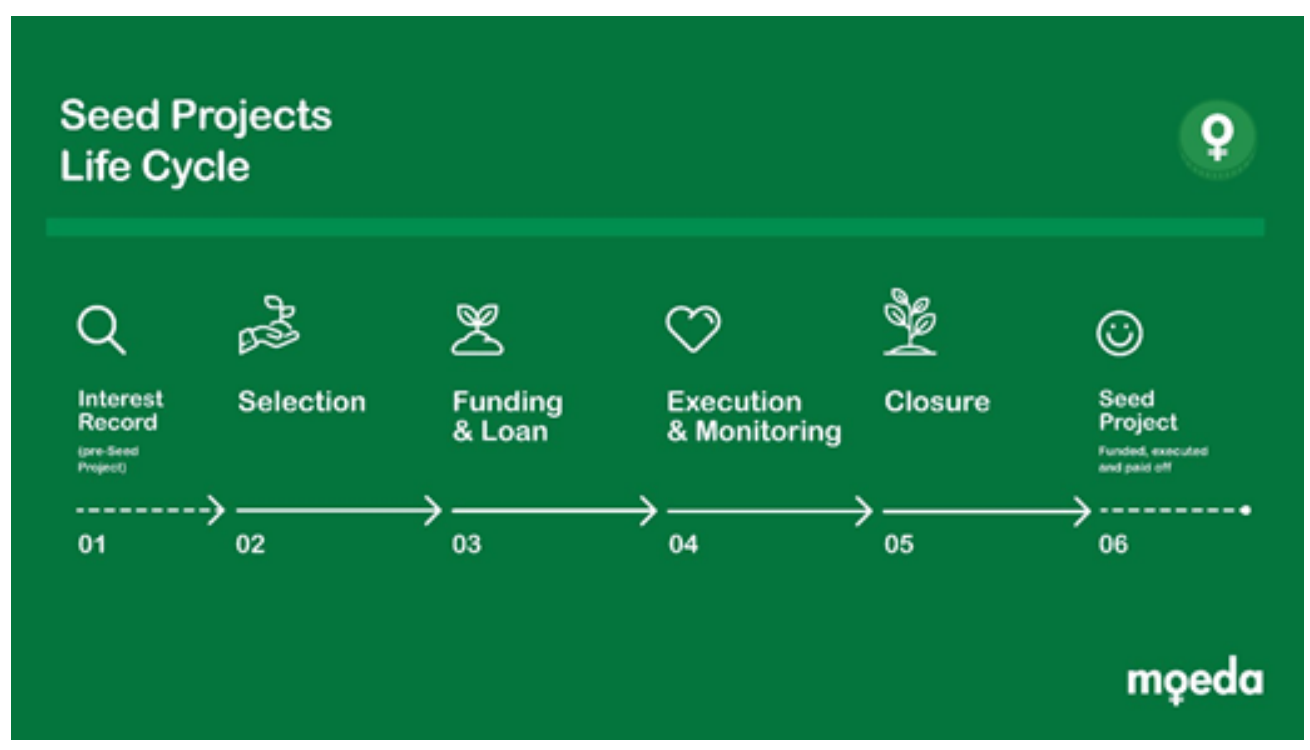

Figure A5. Seed Projects life cycle.

Source: Retrieved from https://moedaseeds.com/ on August 23, 2020.

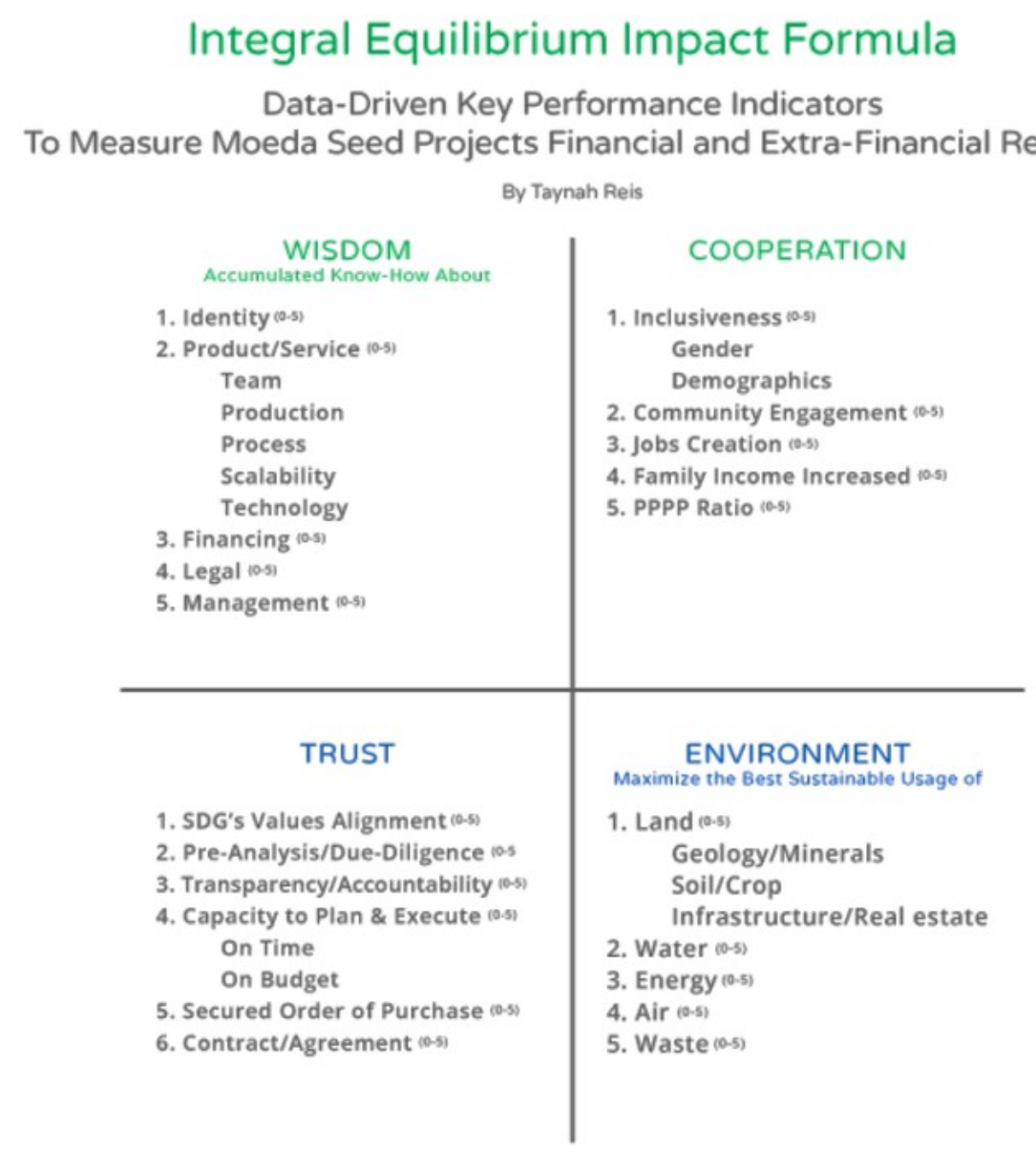

Impact Maximum Score $=100$

Figure A6. The impact formula structure.

Source: Retrieved from https://moedaseeds.com/ on August 23, 2020. 


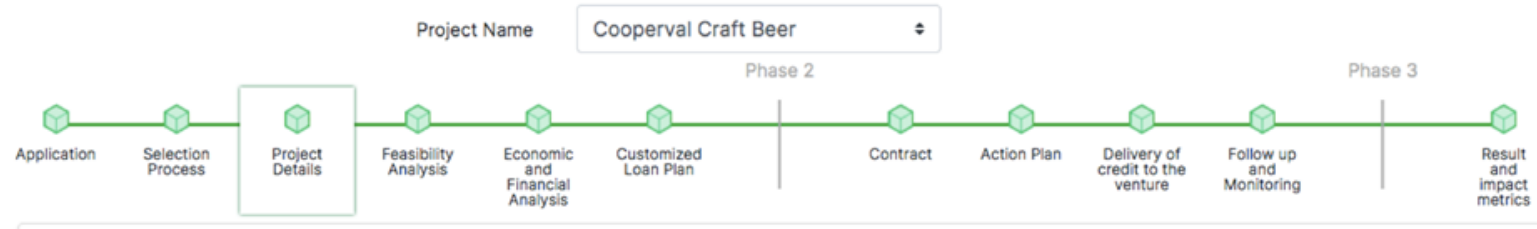

This step consists of receiving the complementary documents and other information about the project. Application of questionnaire,s reports of expert advice on economic and financial matters. Subject video with information about the project, cooperative, participants and products to be launched on the platform. ODS involved in the project are identified and registered.

Submission Number : 0029/2018

Assesments : -

Economic Report : -

Technical Review : -

Executive Briefing : -

Direct Beneficiaries Number : 20

Indirect Beneficiaries Number : 400

Number of Jobs Created: 0

Description (en) :

For over 10 years, Divina and the women from Cooperval produce, process and sell frozen fruit pulp, vegetables and baked goods to feed the schoolchildren in Formosa, Goias. The group wants to boost production and increase their income. In order for them to pay for the financing, Moeda developed a Seed Project focused on the baru, a traditional chestnut from the region. Our business plan provides for a partnership with a local brewery to produce 1,500 bottles of baru craft beer. We will also act in co-branding with the $\| " D o n a$ Divina Baru Beerl|". With the revenue from sales, the cooperative will pay the initial contribution of US\$ 8,000 , including fees, in December 2018. They will also develop the production of baru seedlings and spread the cultivation to more than 3,000 families, turning extractivism into an environmentally relevant commercial activity. In addition, equipment will be purchased to boost productivity using little water and minimal electricity.

\section{Reasons (en):}

To increase the revenues for the cooperative and the families involved, Cooperval needs to develop baru craft beer. It 's therefore necessary to improve the processing of the ingredients, form partnerships, develop revenue and packaging and establish marketing.

Estimated impact (en): This project fulfills 3 of Sustainable Social and Economic Development goals established by the UN

Business oportunity (en) :

To organize the processing of ingredients, increase the labor force, partnership with a local brewery, sommeliers, packaging, labeling, marketing, and machinery.

Moeda Consultant Name : -

Moeda Local Consultant Name : -

Moeda Local Consultant E-mail :

Moeda Local Consultant Company : -

Financial Consultant : -

Financial Consultant contact: -

Detail Participants

$\checkmark$ UN SDG

Goals

View blockchain $\llbracket$

Figure A7. Step-by-step tracking enabled by blockchain technology.

Source: Retrieved from https://moedaseeds.com/ on November 9, 2020. 


\section{Teaching Notes}

\section{ABSTRACT}

Blockchain technology has been explored as a tool to generate social impact. An example of it is Moeda Seeds, a Brazilian ecosystem operating to support financial inclusion and gender equality, two UN sustainable development goals, by facilitating access to microfinance for female entrepreneurs with social impact projects. Traditionally facing difficulties to access credit in the traditional banks, the selected Seed Projects are also granted with management support from Moeda's ecosystem to optimize its entire chain efficiency and helping them to promote long-term sustainable practices for the local communities to thrive. This whole ecosystem is enabled by a blockchainbased payment and lending platform and Moeda's proprietary digital tokens, which people around the world can promptly and transparently invest while participating in sustainable growth. This teaching case brings the COVID-19 crisis as background panorama and the founder Taynaah Reis in the center of an urgent strategic decision-making process. It covers the difficulties, variables, and alternatives presented to structure a contingency plan during that period of high uncertainty. It is extended by the teaching notes, covering: social cryptocurrencies, blockchain, digital platform, online sales, network externalities, and e-commerce ecosystem.

Keywords: blockchain; COVID-19; social development; digital platform; e-commerce.

\section{RESUMO}

A tecnologia blockchain tem sido explorada como ferramenta para gerar impacto social. Um exemplo disso é a Moeda Seeds, um ecossistema brasileiro que apoia a inclusão financeira e a igualdade de gênero, dois objetivos de desenvolvimento sustentável da ONU, facilitando o acesso a microfinanças para empreendedoras com projetos de impacto social. Tradicionalmente enfrentando dificuldades para acessar crédito nos bancos tradicionais, os projetos Seeds selecionados recebem também apoio em gestão, de modo a otimizar a eficiência da cadeia e ajudá-los a promover práticas sustentáveis de longo prazo. Todo ecossistema é habilitado por uma plataforma de pagamento e empréstimo baseada em blockchain e tokens digitais proprietários da Moeda, nos quais pessoas em todo o mundo podem investir de forma rápida e transparente enquanto participam de um crescimento sustentável. Este caso de ensino traz a crise de COVID-19 como panorama de fundo e a fundadora Taynaah Reis no centro de um processo estratégico urgente de tomada de decisáo. Abrange as dificuldades, variáveis e alternativas apresentadas para estruturar um plano de contingência em um período de alta incerteza. É estendido pelas notas de ensino, abrangendo: criptomoedas sociais, blockchain, plataforma digital, vendas on-line, externalidades de rede e ecossistema de comércio eletrônico.

Palavras-chave: blockchain; COVID-19; desenvolvimento social; plataforma digital; comércio eletrônico.

\section{APPLICATION}

This teaching case was designed to undergraduate and postgraduate Administration programs. It can be used in courses of Entrepreneurship and Innovation, Finance involving digital currencies, microfinance, or sustainable investment, and Marketing involving digital business models and marketplaces. It can also be applied in any other subject that covers social entrepreneurship, digital platform ecosystems, blockchain and social cryptocurrencies, or logistics outsourcing.

\section{LEARNING OBJECTIVES}

After reading and discussing this case, participants should be able to: (a) recognize challenges faced by social entrepreneurships to create and innovate their processes; (b) understand the opportunities and challenges of blockchain technology and cryptocurrencies as tools to generate social impact; (c) learn and apply concepts of online market entry, digital platform evolution, network and externality effects, and e-commerce ecosystem management in a business context. 


\section{ASSIGNMENT QUESTIONS}

Different questions can be proposed for this case study preparation, depending on the established learning objectives for the discussion and the participants' level of knowledge. Find below a core guidance of questions as a suggestion aligned with these teaching notes:

- What are the main problems that Moeda Seeds addresses? How do they support entrepreneurs beyond traditional bank loans?

- What is Moeda Seeds innovative business approach to reinvent the way people invest? How do they add value to investors?
- What is a complementary cryptotoken? How do they support local development?

- Define blockchain, cryptocurrency, and token in your own words. What is the difference between them? How do they fit in Moeda's solution proposition?

- In your opinion, which alternative should Taynaah choose concerning the COVID-19 crisis? Why?

\section{THEORETICAL ANALYSIS}

In the next topics, we present some concepts and references, which can be articulated in the discussion of this case. All figures were developed by the authors.

\section{(A) Blockchain and social cryptocurrencies}

\begin{tabular}{|l|l|}
\hline $\begin{array}{l}\text { Blockchain is a revolutionary way to store and preserve data, which allows trust, transparency, and } \\
\text { immutability of information. These characteristics are relevant in most of cryptocurrencies, including } \\
\text { Moeda Seeds' ecosystem. }\end{array}$ & $\begin{array}{l}\text { Gartner Inc. (2020), Moeda Seeds (2019a), } \\
\text { Tapscott and Tapscott (2018). }\end{array}$ \\
\hline $\begin{array}{l}\text { Cryptocurrencies are those currencies created with cryptography, which generally seek to distribute control } \\
\text { over the platform. Cryptotokens usually represent an asset or utility, being categorized into three types: } \\
\text { currency tokens, utility tokens, and investment/asset tokens. }\end{array}$ & $\begin{array}{l}\text { Cernev and Diniz (2019), Diniz, Cernev, } \\
\text { Rodrigues, and Daneluzzi (2020). }\end{array}$ \\
\hline $\begin{array}{l}\text { Social cryptocurrencies are those cryptoassets adopted or used for social and local development purposes, } \\
\text { including cryptocurrencies and tokens. Based on blockchain technology and solidarity finance, they generally } \\
\text { have distinct design, governance, characteristics, and purposes from the best-known cryptocurrencies, such } \\
\text { as Bitcoin and Etherium. The Moeda Seeds ecosystem consists of four different cryptocurrencies and tokens, } \\
\text { which makes it a unique case. }\end{array}$ & Moeda Seeds (2019a), Diniz et al. (2020). \\
\hline
\end{tabular}

Figure 1. Main concepts regarding blockchain and cryptocurrencies.

\section{(B) Digital platform evolution and management}

In the short term, which is the case of actions related to the COVID-19, a platform should care about resilience and scalability, in the
operational level, and composability at the strategic level.
Resilience of a platform is the capacity to function acceptably in the event of a failure elsewhere within or outside the ecosystem. To
increase resilience requires modularizing a platform's interfaces, deliberately introducing some redundancy in its internal design, and
increasing the degree to which the platform is internally monolithic.
Scalability is the degree to which a platform's functional performance and financial viability are not dependent of size. It encompasses
size changes either upward or downward related to the two sides of the platform.
Composability encompasses the ease with which changes can be made within a platform without breaking its interoperability with other
elements of the ecosystem.
Alignment between governance and architecture of a platform is key to improve its resilience, scalability, and composability.

Figure 2. Main concepts related to digital platform management.

\section{(C) Network externalities effects and multi-sided markets}

Network effects are the incremental benefit gained by an existing user for new users that join the network. In two or multiple-sided markets, it can also be called cross-side effects. As the name suggests, it is the increased value of a good or service for one side group of users when new users from a different side join the network.

In a platform business, a coordinated network effect from both sides is essential to achieve a balanced and sustainable growth. This effect becomes relevant after hitting a certain number of users, usually called critical mass, often taking advantage of externalities to increase its value. This is why a key element to make this system work is to focus on getting users to join as fast as possible, which means that the major difficulty for Moeda, if the decision is to go for Moeda's marketplace, is to get critical mass.
Hagiu (2014), Shapiro and Varian (2003).

Figure 3. Multi-sided markets and network externalities. 


\section{(D) Online sales and type of seller relationship}

When it comes to online sales, there are three main types of seller relationship, which can be mixed and matched to result in variation types or even hybrid models.

Also known as retail relationship, the first party (1P) occurs when the supplier ships the product directly to consumers, which means having total control over the product. The responsibility of the retail price set, marketing, storage, and shipment is entirely of the owner. Whereas the second-party relationship (2P), although there is no consensus in its definition, the one chosen here is that it can be characterized by a strong partnership with a marketplace, which becomes responsible for the product storage and shipment. In this case, the owner sells through the marketplace, still having control over the pricing and inventory but conveniently renting a space in the partner's fulfillment center. Lastly, the third-party relationship (3P) has also a marketplace partner where it sells through, like the $2 \mathrm{P}$, but it maintains total control of the product's storage and shipment. It differs from the $1 \mathrm{P}$ because it is not necessary to create its own place to display the products, since the owner can count on the marketplace, benefiting from the partner's poll of customers.

The type of seller relationship choice is usually linked with a trade-off: the more support received from a partner, the higher the fee charged. Therefore, a marketplace partner is probably going to charge more in a $2 \mathrm{P}$ relationship, since it gives more convenience for the supplier than the 3P. As for the $1 \mathrm{P}$, although there are no middlemen getting a piece of profits, it can result in lower total profits due to online sales disadvantages of not being present in a marketplace, such as fewer sales, customers, etc. Usually, this happens with small businesses, which do not have the size to be relevant in the online market by itself (on its own) or do not have the capabilities to be autonomous. This is the case for most of Seed Projects, which means that the probability of their survival is higher when they rely on a partner. Now, in the decision between the 2P and 3P, Moeda should first evaluate the trade-off between creating its own marketplace and selling through an existing marketplace. While this last option has the advantage of having the poll of customers and the logistics know-how, none of the main marketplaces in Brazil has the know-how to manage perishable products storage. Which means that depending on how fast they can develop this expertise, whereas if Moeda creates its own marketplace it will have total control of the speed they manage to expand the laboratorial initiative and also the process quality, a sensitive variable when it comes to food and beverages.

\section{(E) Other theoretical approach}

Other theoretical perspectives that could support the analysis of this teaching case would be logistic outsourcing, discussed by Akbari (2018), and the make-or-buy decision, analyzed by Lowndes (2018).

\section{QUESTIONS FOR DISCUSSION}

\section{What is a cryptoasset and how does it work? How do all proprietary cryptotokens interact with each other and fit/work together in Moeda's ecosystem?}

The goal for this question is to balance participants' level of knowledge about Moeda's business model. To do so, it is recommended to start by assuring everyone knows some basic concepts. Thus, the instructor can ask someone to explain what a cryptoasset is and what are the differences between some other concepts like blockchain and cryptotoken.

With those concepts made clear, the instructor could ask how a cryptoasset works by itself and interacting with other cryptoassets. If anyone gives Moeda's case as an example, he/she could introduce it subsequently to start a discussion of how the cryptoassets fit together in Moeda's ecosystem and how they fit and work together to support Moeda's mission. It is expected that the participants recognize the innovative business approach that combines more than one cryptocurrency, each one having its own function, to work toward Moeda's solution proposition.

At this point, it is important for the remaining discussion that the instructor emphasizes that Moeda Seeds is a social business, so participants put that in consideration during the analysis of the alternatives. For this reason, it is suggested to play the video showing the reality of an entrepreneur supported by Moeda (see support materials). It is important to remind that Moeda's main purpose is to support those female entrepreneurs in communities with high economic vulnerability, which means that the decisionmaking in this case is not just a business decision, since Moeda would lose its purpose if it prioritizes itself and leaves its central and most vulnerable stakeholders hanging out dry at the same time.

Therefore, as a transitioning question, the instructor could ask "what is the real problem presented in the case?" and, further on, "what is the real problem entrepreneurs supported by Moeda are facing?" or "what kind of help do entrepreneurs need from Moeda?" 


\section{What are the existing platforms models of e-commerce? How do they differ?}

This question is intended for participants to recognize the existing models of e-commerce and, more specifically, the three types of party relationship in an online sale. The instructor could ask what types of online sales the participants would consider if they were going to start a small business and why. After that, it is suggested that the concept of first-, second-, and third-party relationships be introduced, connecting with the participants' options and examples.
To make the distinction clear, the instructor could assist with questions that refer to the different dimensions of comparison, writing the contributions on the board. What are the parts involved? Who is responsible for what? What are the advantages for the supplier in each case? Table 1 resumes some of those characteristics.

Then, the instructor could ask participants to step into the shoes of the suppliers first and then into the marketplace's. As an exercise, they should be able to evaluate Moeda's position as a business and as a social business to support microentrepreneurs.

Table 1. Types of seller relationship's comparative dimensions.

\begin{tabular}{|c|c|c|c|}
\hline Dimensions & $1 \mathrm{P}$ & $2 \mathrm{P}$ & $3 \mathrm{P}$ \\
\hline \multirow[b]{2}{*}{ Main characteristics } & Sale directly TO the customer & Sale THROUGH the marketplace & Sale THROUGH the marketplace \\
\hline & $\begin{array}{l}\text { Supplier has } 100 \% \text { control of the } \\
\text { product and the sale }\end{array}$ & $\begin{array}{l}\text { Marketplace with fulfillment and } \\
\text { shipment responsibilities }\end{array}$ & $\begin{array}{l}\text { Marketplace helps with the online } \\
\text { sale }\end{array}$ \\
\hline \multirow{2}{*}{ Best fit for } & $\begin{array}{l}\text { Strong brands, high value-added or } \\
\text { made-to-order products }\end{array}$ & $\begin{array}{l}\text { Smaller suppliers without the } \\
\text { necessary infrastructure }\end{array}$ & $\begin{array}{l}\text { Products that require special } \\
\text { handling or are made-to-order }\end{array}$ \\
\hline & Who wants customization & Who wants convenience & $\begin{array}{l}\text { Who wants assistance just for the } \\
\text { sale }\end{array}$ \\
\hline Trade-offs & $\begin{array}{l}\text { No fees but has to generate online } \\
\text { traffic on its own }\end{array}$ & $\begin{array}{l}\text { Higher convenience and higher fees } \\
\text { for the marketplace }\end{array}$ & Fee for the marketplace \\
\hline Perceived value by customers & Personalized customer service & $\begin{array}{l}\text { Speed delivery plus direct } \\
\text { comparison }\end{array}$ & $\begin{array}{l}\text { Direct comparison } \\
\text { competitors }\end{array}$ \\
\hline
\end{tabular}

\section{What are the market entry barriers and challenges for new players in the e-commerce ecosystem?}

At this point, the instructor could ask participants, in small groups, to discuss the market barriers and other challenges for new players to enter the e-commerce ecosystem. It is expected that participants think on challenges of the three types of party relationship in both perspectives: supplier and marketplace.

From the suppliers' perspective, participants should raise issues such as the toughness of attracting clients to its own website when there is an online marketplace where clients can find pretty much anything. Thus, they should presume there is a trade-off between having its own e-commerce, keeping $100 \%$ of the profits, and being part of a renowned marketplace with a large poll of customers in exchange for a fee. Among the difficulties of opening their own e-commerce, participants should consider responsibilities like fulfillment and logistics, digital payments and antifraud, taxes and documents, etc. Figure 4 details an e-commerce ecosystem and complementary services.

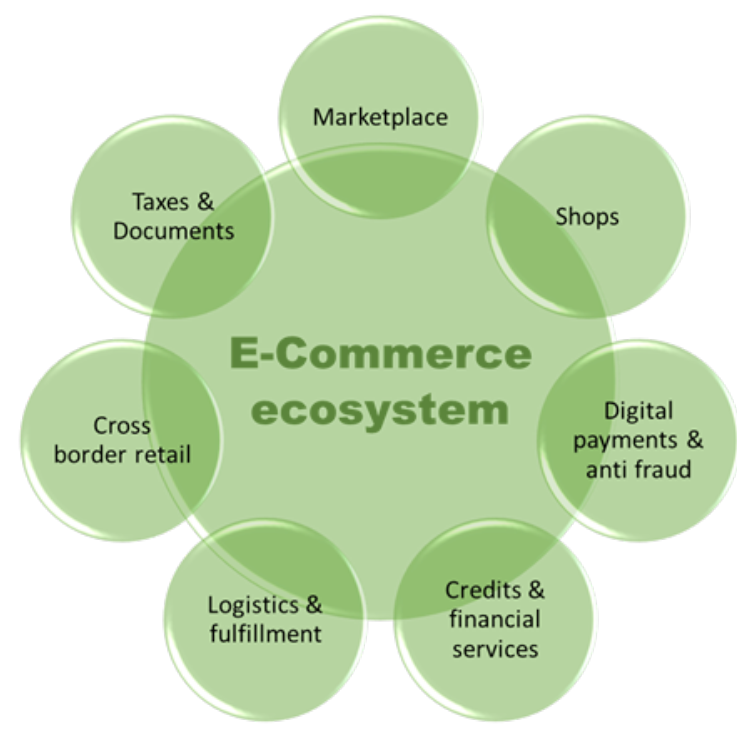

Figure 4. E-commerce ecosystem framework.

From the marketplace's perspective, participants are expected to think about the challenges to enter that market, such as building the website, negotiating with the stakeholders, achieving the critical mass, among others. If 
not mentioned before, it is recommended that the concept of network and externalities effects be introduced.

As a transition to the next question, the instructor could do a quick survey, questioning participants which alternative they would choose if they were Taynaah.

\section{What are the pros and cons of the alternatives presented in the case?}

Once more, the instructor could give 10 to 15 minutes for participants to discuss the pros and cons of the case alternatives in small groups. On the cons side, it is expected that participants go beyond the market entry barriers discussed before, approaching weaknesses, limitations, difficulties, and any other challenges. On the pros side, participants should think of strengths, advantages, and opportunities considered relevant to this decisionmaking process.

For alternative $\mathrm{A}$, the positive side for Moeda is that it would not take any extra direct risks, since there will not be any abruptly change in strategy. Yet, it would have to increase its commercialization support for more than 200 projects to help each one migrate to online sales. Besides, it would also increase the chances of most Seed Projects to become irrelevant on their own, due to the high concentration of the Brazilian online marketplace, increasing Moeda's indirect risks eventually.

About alternative B, a huge part of the entrepreneurs' direct risks would be transferred to Moeda, since it would take full responsibility for the fulfillment and logistics, along with a high investment required to build the necessary infrastructure. In this scenario, one of Moeda's biggest challenges would be reaching the critical mass on both supply and demand sides at the beginning of the marketplace creation, a fundamental part to get the positive effects of network externalities but especially tough to reach due to the Brazilian marketplace high concentration. As for the positive side, once Moeda hit the critical mass, Seed Projects would benefit from its effects. Until they get there, the entrepreneurs would receive complete support from Moeda, which would also have total control over the marketplace construction and quality procedures.

The alternative $\mathrm{C}$ is similar to alternative $\mathrm{B}$, with the difference that entrepreneurs would keep the control of fulfillment and logistics along with Moeda's commercialization support. This means that Moeda's investment and risks would be lower than in alternative
$B$, but entrepreneurs' support would be higher than in alternative A, since Moeda would take care of the marketplace platform itself and must have features in today's e-commerce ecosystem like digital payments, delivery tracking, etc. In addition, as in the previous alternative, Moeda would have total control over the marketplace development, not being dependent on a third party for its launch as it might be in alternative D. Therefore, this scenario would present a better balance between Moeda's and the entrepreneurs' responsibilities, risks, and resources investment.

In alternative $\mathrm{D}$, Moeda would not have any direct risk, since it would rely on a third-party marketplace. This means that along with Moeda's commercialization support, entrepreneurs would also receive support from an already consolidated marketplace and benefit from its poll of customers. On the other hand, entrepreneurs might not be the priority for this partner, since they probably will not be relevant considering the partner's portfolio of suppliers. In addition, marketplaces profit from a flat or percentage fee of each sale, which means a piece of profit margin from Seed Projects would be directed to middlemen. Lastly, since none of the consolidated marketplaces in Brazil has the necessary expertise to manage food and beverages yet, there would be a high dependence on the partner's prioritization to develop it (especially perishable items, which most Moeda's products are), but it might also be an opportunity to take a step ahead of competitors in a period when the sales of essential items are rising.

The alternative $\mathrm{E}$ might sound as an interesting choice due to its goal of fostering online sales. However, it would not solve the main issue presented in the case, which is how to enter the e-commerce ecosystem and build the foundations to make the first online sale. For this reason, this alternative should be excluded.

Afterwards, the instructor can call everyone back to the board and consolidate the discussion in a comparison chart as follows (Table 2).

If necessary, at this point the instructor can remind the participants that Moeda is a social business and its targeted audience is mostly female microentrepreneurs in economically excluded communities, which means it is not a simple business decision for Moeda. 
Table 2. Positive and negative aspects of alternatives presented in the case.

\begin{tabular}{|c|c|c|}
\hline Alternatives & Pros & Cons \\
\hline \multirow{3}{*}{ A. Individual support } & \multirow{3}{*}{ No direct risks for Moeda } & High simultaneous demand for support (+200 projects) \\
\hline & & Brazilian marketplace high concentration \\
\hline & & High chances of irrelevance \\
\hline \multirow{3}{*}{$\begin{array}{l}\text { B. Moeda's marketplace with } \\
\text { fulfillment and delivery }\end{array}$} & Total control over platform development & Brazilian marketplace high concentration \\
\hline & Direct commercialization support & Huge challenge to hit the critical mass \\
\hline & Network effect benefit if it hits the critical mass & High investment and direct risks (warehouse and logistics) \\
\hline \multirow{4}{*}{$\begin{array}{l}\text { C. Moeda's marketplace without } \\
\text { fulfillment and delivery }\end{array}$} & Total control over platform development & Brazilian marketplace high concentration \\
\hline & Direct commercialization support & Huge challenge to hit the critical mass \\
\hline & Network effect benefit if it hits the critical mass & \multirow[b]{2}{*}{ Simultaneous demand for support (+200 projects) } \\
\hline & $\begin{array}{l}\text { Seed entrepreneurs keep storage and shipment } \\
\text { responsibilities }\end{array}$ & \\
\hline \multirow{3}{*}{ D. Third-party marketplace } & Benefit from the partner's poll of customers & Higher piece of profit margin directed to middlemen \\
\hline & Direct commercialization support & \multirow{2}{*}{ High dependence on marketplace partner } \\
\hline & Lower investment and risks for Moeda & \\
\hline E. New token & No direct risks for Moeda & Does not solve the main issue \\
\hline
\end{tabular}

\section{Which alternative do you think Taynaah should choose? Why? In your opinion, how should she deal with this crisis management?}

After analyzing all the pros and cons together with the class, a second quick live survey with participants could be done, also questioning if anyone switched their opinions and why. Subsequently, the instructor can link the main decision presented in the case with other crisis management decisions such as the decision-making process promptness, engagement with stakeholders, e-commerce platform management responsibilities, and any other factors that may be considered relevant. To help participants, the instructor could ask questions like "how quick do you think this decision-making process should be? How close would you involve Moeda's stakeholders in this decisionmaking process?" and for who has chosen the alternatives B or C, "if you were Taynaah, would you keep the platform management below Moeda's ecosystem? Or would you open a whole new business to take care of it since a marketplace is very different from Moeda's core business?"

As a conclusion, the instructor could quickly summarize the main points of the discussion or ask participants to highlight the most important points they have learned.

\section{SUGGESTED TEACHING AND DISCUSSION PLAN}

Introduction (5-15 minutes): in case participants have not received the preparation questions as a pre-reading, the instructor could give some time for participants to read it and briefly discuss in small groups. Those questions target to balance participants' level of knowledge of some concepts that will be approached during the discussion.

Innovation process (15-20 minutes): to start the discussion, the instructor could approach the suggested discussion questions, one at a time. On the first question, it is suggested that an introduction video be presented, showing the whole process of how it is to invest with Moeda, from buying MDA token to choosing the project, and track it as they go through the acceleration process until they deliver their first product and the investors receive their earnings. Here, the instructor could also write down the highlights mentioned about Moeda's business model, especially its unique and innovative characteristics. In case of doubts, the instructor could also ask if another participant could answer it to start engaging participants and check whether the content is clear.

E-commerce platform model (5-10 minutes): once the main issue is broached, the instructor may start approaching the different forms to make an online sale or asking participants for examples of ways to make it. When convenient, the instructor could bring up the concept of 
first-, second-, and third-party relationships comparing all of them while writing on the board in a comparison table. If necessary, some complementary questions on specific dimensions could be made, such as responsibilities of each party, fees, and perceived value from final customers.

E-commerce ecosystem (15 minutes): at this moment, the instructor could broaden the discussion to the whole e-commerce ecosystem, analyzing other variables and issues that need to be handled before making an online sale. To support the explanation, the instructor could start drawing the e-commerce ecosystem framework and ask for contributions. When pertinent and if it was not mentioned earlier, the concept of network externalities effects can be introduced in a marketplace context, also emphasizing its importance for achieving a sustainable growth.

Analysis of the alternatives ( 25 minutes): to deepen in the alternatives' discussion, it is suggested that the instructor ask participants to contribute with their perceptions and, whenever possible, contrast them using other participants' opinions. It is also suggested that a comparison table approaching the pros and cons is drawn on the board.

Crisis management (5-10 minutes): after discussing the alternatives, a second quick live survey could be done, this time asking if anyone has changed their mind and if yes, why. Afterwards, other topics related to crisis management could be explored, such as the decision-making process promptness, engagement with stakeholders, e-commerce platform management responsibilities, and any other elements that may be relevant for the discussion.

Wrap-up (5-10 minutes): as a conclusion for the discussion, the instructor could provide a brief overview of the main topics, concepts, and situations discussed. More than having a single answer for the case, it is important that participants learn how to explore and exploit variables, evaluating complex situations, and manage to deal with a decision-making process like the one presented in the case. At the end of the discussion, the participants' contribution can be organized on the board as following.

Types of Seller Relationship Comparative Dimensions

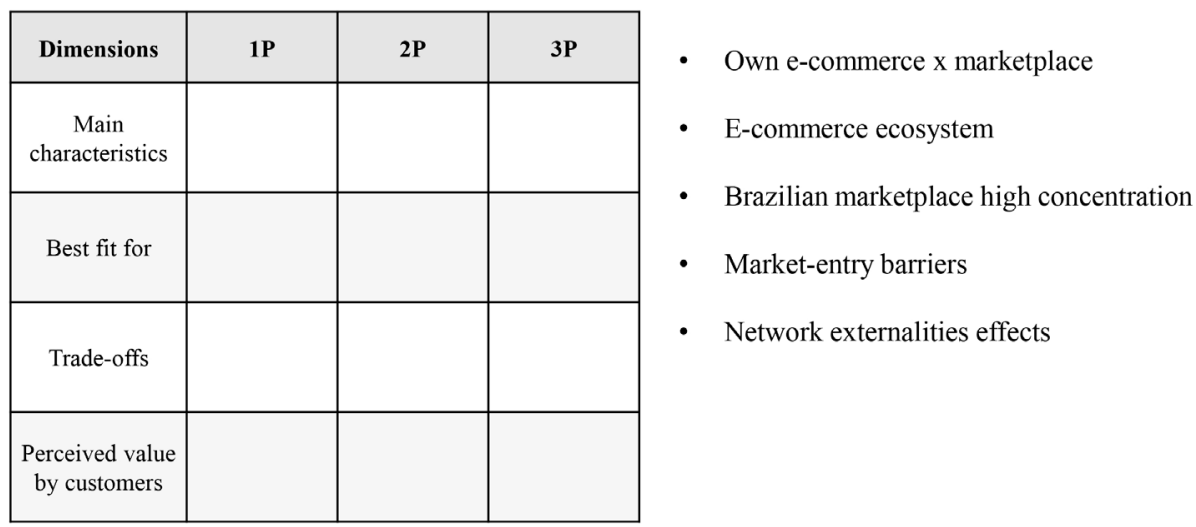

Figure 5. Example of discussion notes on the board.

\section{Analysis of Case Alternatives}

\begin{tabular}{|c|c|c|c|}
\hline Alternatives & PROS & CONS & - Types of seller relationship \\
\hline A. Individual support & & & - More than a business decision \\
\hline $\begin{array}{l}\text { B. Moeda's marketplace } \\
\text { with fulfillment and } \\
\text { delivery }\end{array}$ & & & - Moeda's target public context and limitations \\
\hline $\begin{array}{l}\text { C. Moeda's marketplace } \\
\text { without fulfillment and } \\
\text { delivery }\end{array}$ & & & - Challenges and opportunities \\
\hline $\begin{array}{l}\text { D. Third-party } \\
\text { marketplace }\end{array}$ & & & - Crisis management decision-making \\
\hline E. New token & & & \\
\hline
\end{tabular}

Figure 6. Example of discussion notes on the board. 


\section{SUPPORT MATERIALS}

Some support materials may be used or suggested by the instructor in the preparatory phase or during discussions of this teaching case:

- Moeda’s channel on YouTube (Moeda TV, 2018).

- Moeda's website with Seed Projects (Moeda Seeds, 2020b).

- Video about Moeda and COVID-19 at UN event (Moeda TV, 2020).

- About Seed's projects (Moeda Seeds, 2020b).

- Seeds Explorer: Moeda's blockchain-based tracking board (Seeds Explorer, 2020).

- Moeda Seeds Market (Moeda Market, 2020).

- Mercado Livre's website category of sustainable products (Mercado Livre, 2020).

\section{HOW THE STORY UNFOLDS}

Two weeks after the COVID-19 crisis hit Brazil, Taynaah started the contingency plan's implementation. Her final decision was to invest Moeda's resources on expanding the marketplace lab experiment, now called Moeda Market. With that strategy, Moeda kept $100 \%$ control of the platform while giving direct commercialization support for the entrepreneurs. Four months later, although a good progress was already made, it is still too soon to see if Moeda managed to hit the critical mass of the two-sided market in a way both sides benefit from network externalities effects.

Taynaah also launched the project VVIDAA, which proposes practical courses of actions by giving incentives to local farmers in Brazil to enhance food security protection (see pictures below). This was an important factor since most of Seed Projects handle agricultural products and the food sector requires high standards of security, especially with the COVID-19 pandemic.
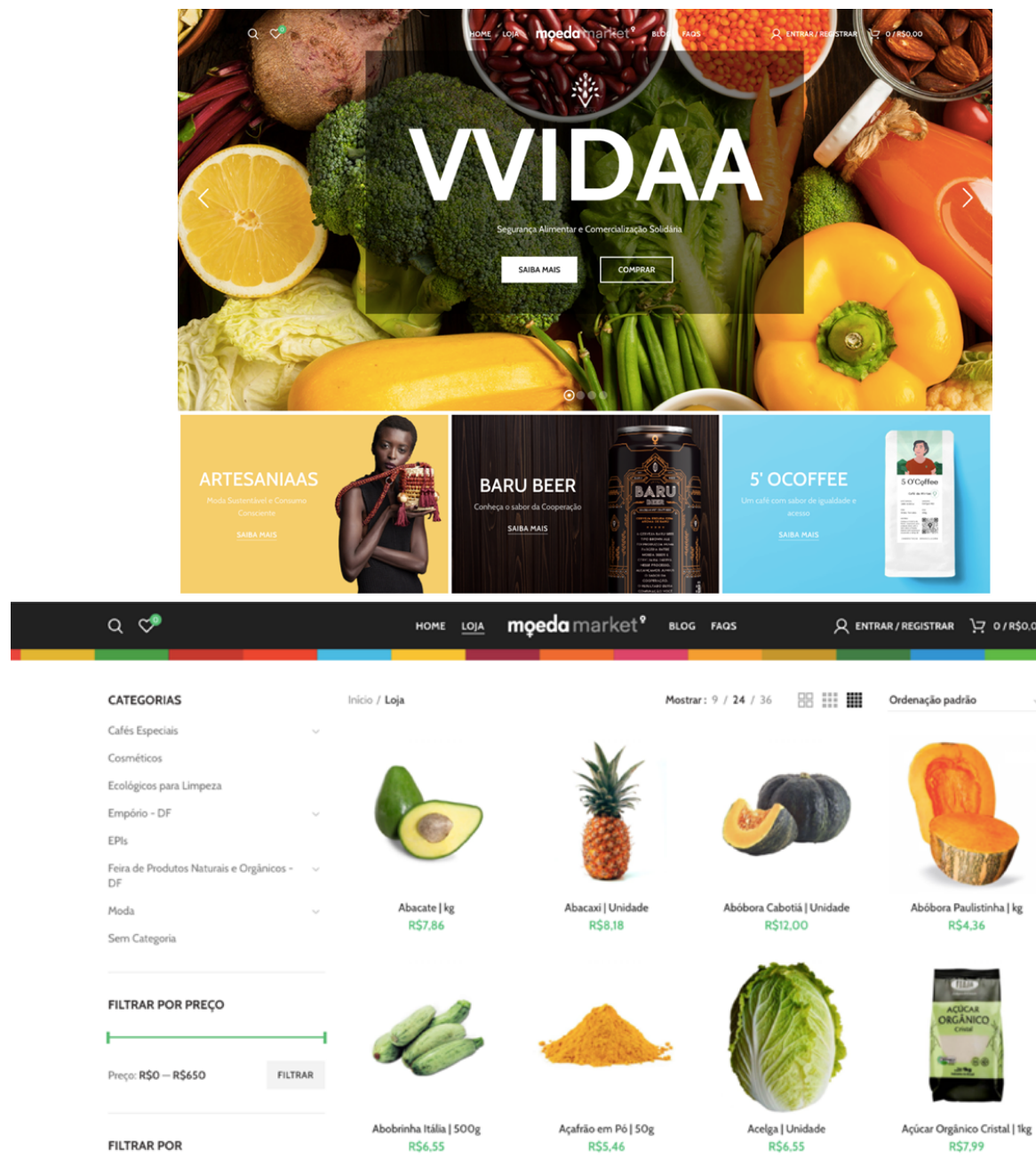

Figure 7. VVIDAA website. 

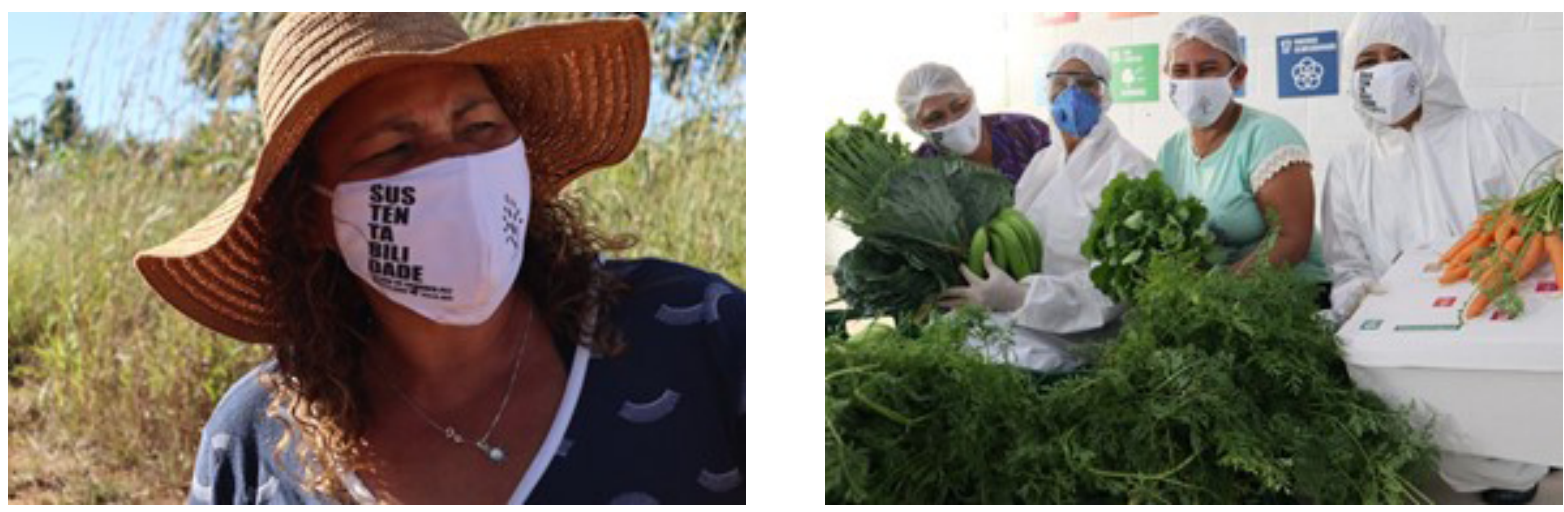

Figure 8. Local farmers supported by project VVIDAA in Brazil.

Source: Moeda Seeds (2020a).

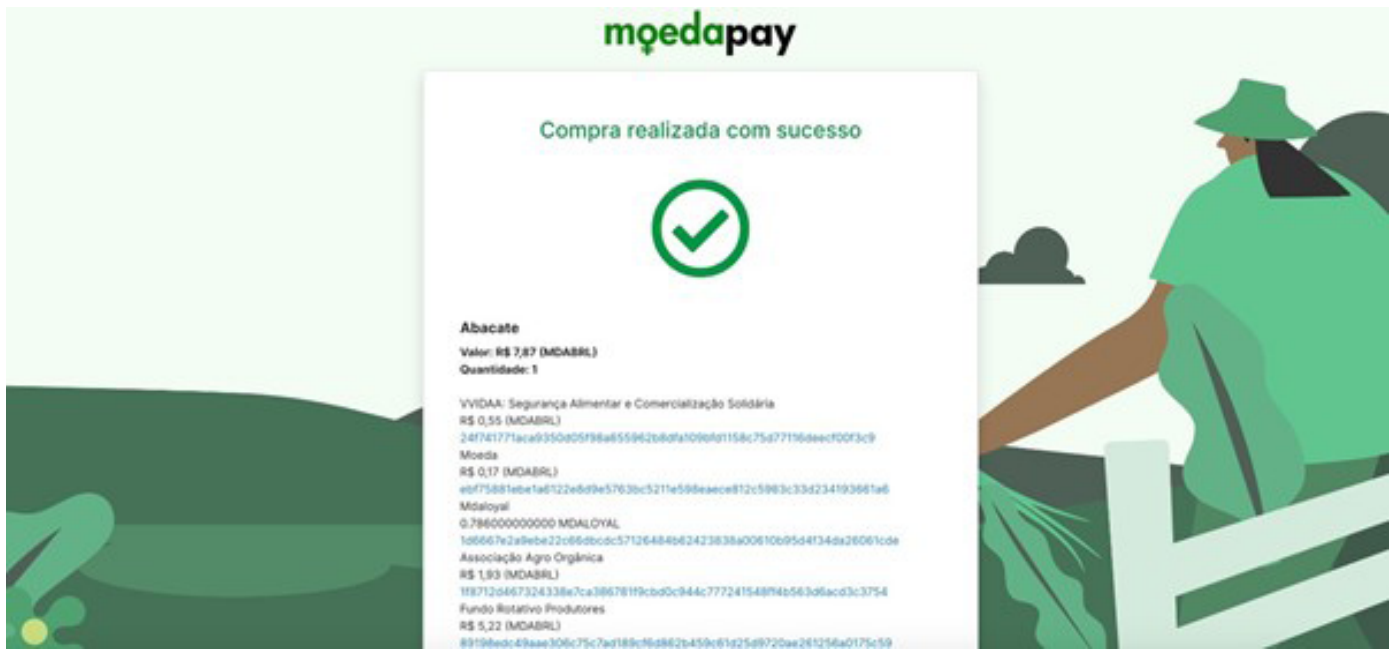

Figure 9. Purchase paid with MoedaPay.

Source: Moeda Seeds (2020a).

\section{REFERENCES}

Akbari, M. (2018). Logistics outsourcing: A structured literature review. Benchmarking: An International Journal, 25(5), 1548-1580. https://doi.org/10.1108/BIJ-04-2017-0066

Cernev, A., \& Diniz, E. (2019). Blockchain: A nova revolução tecnológica nos serviços. In P. Tigre, \& A. Pinheiro (Orgs.), Inovação em serviços na economia do compartilhamento. São Paulo: Saraiva.

Diniz, E., Cernev, A., Rodrigues, D., \& Daneluzzi, F. (2020). Solidarity cryptocurrencies as digital community platforms. Information Technology for Development, v. 27. https://doi.org/10.1080/02681102.2020.1827365

Gartner Inc. (2020). Hype cycle for blockchain business. Retrieved from www.gartner.com
Hagiu, A. (2014). Strategic decisions form multisided platforms. MIT Sloan Management Review, 55(2). Retrieved from https://store.hbr.org/product/strategic-decisions-formultisided-platforms/SMR477

Lowndes, M. (2018). Align your approach to the emerging digital commerce platform landscape to make buy or buy-andbuild decisions. Retrieved from https://www.gartner. com/en/documents/3895277/align-your-approach-to-theemerging-digital-commerce-pla

Mercado Livre. (2020). Produtos sustentáveis. Retrieved from https://cutt.ly/epcqtB4

Moeda Market. (2020). Moeda Seeds Market. Retrieved from https://moedamarket.com/ 
Moeda TV. (2018). Moeda. TV Youtube channel. Retrieved from https://www.youtube.com/channel/UCYKNfrimYVgoJP2Du-k7Mw

Moeda TV. (2020, October 20). Evento ONU: O papel do empreendedorismo na retomada pós covid-19 [Video file]. Video posted to https://youtu.be/x0PxzLTYSNM

Moeda Seeds. (2019a). Moeda: Global ecosystem for financial inclusion \& sustainable development growth. Moeda's white paper 2.0. Retrieved from http://www.filedropper.com/moedaswhitepaper20

Moeda Seeds (2020a). Moeda Seeds Portal. Retrieved from https://moedaseeds.com/

Moeda Seeds. (2020b). Apoie nossos Projetos Semente. Retrieved from https://moedaseeds.com/projects/

\section{Authorship}

\section{Letícia Cristina Kanegae}

Fundação Getulio Vargas, Escola de Administração de Empresas de São Paulo

Rua Itapeva, no 474, Bela Vista, 01313-902, São Paulo, SP, Brazil

E-mail address: 1ckanegae@gmail.com

(1) https://orcid.org/0000-0002-2147-7030

\section{Adrian Kemmer Cernev*}

Fundação Getulio Vargas, Escola de Administração de Empresas de São Paulo

Rua Itapeva, no 474, Bela Vista, 01313-902, São Paulo, SP, Brazil

E-mail address: adrian.cernev@fgv.br

(1) https://orcid.org/0000-0002-6300-3976

\section{Eduardo Diniz}

Fundação Getulio Vargas, Escola de Administração de Empresas de São Paulo

Rua Itapeva, no 474, Bela Vista, 01313-902, São Paulo, SP, Brazil

E-mail address: eduardiniz@gmail.com

(1) https://orcid.org/0000-0002-7950-9146

* Corresponding Author

\section{Funding}

The authors reported that there is no financial support for the research in this article.

\section{Conflict of Interests}

The authors have stated that there is no conflict of interest.

\section{Copyrights}

RAC owns the copyright to this content.
Seeds Explorer. (2020). Tracking board. Retrieved from https:// moedaseeds.mybluemix.net/7a1e1a65-7d0f-446d-801fedbf7e77407e

Shapiro, C., \& Varian, H. (2003). A economia da informação: Como os princípios econômicos se aplicam à era da Internet. Rio de Janeiro: Elsevier.

Shen, S. (2020). Three ways to jump start digital commerce. Retrieved from https://www.gartner.com/en/documents/3985334/3ways-to-jump-start-digital-commerce

Tapscott, D., \& Tapscott, A. (2018). Blockchain revolution: How the technology behind bitcoin and other cryptocurrencies is changing the world. New York: Portfolio.

Tiwana, A. (2014). Platform ecosystems: Aligning architecture, governance, and strategy. Burlington, MA: Morgan Kaufmann.

\section{Authors' Contributions}

$1^{\text {st }}$ author: conceptualization (lead); data curation (equal); formal analysis (equal); methodology (lead); project administration (lead); writing-original draft (lead); writingreview \& editing (equal).

$2^{\text {nd }}$ author: conceptualization (lead); data curation (equal); formal analysis (equal); methodology (lead); project administration (lead); validation (lead); writing-original draft (supporting); writing-review \& editing (equal).

$3^{\text {rd }}$ author: conceptualization (supporting); data curation (equal); methodology (supporting); validation (lead); writingoriginal draft (supporting); writing-review \& editing (equal).

\section{Plagiarism Check}

The RAC maintains the practice of submitting all documents approved for publication to the plagiarism check, using specific tools, e.g.: iThenticate.

\section{Peer Review Method}

This content was evaluated using the double-blind peer review process. The disclosure of the reviewers' information on the first page, as well as the Peer Review Report, is made only after concluding the evaluation process, and with the voluntary consent of the respective reviewers and authors.

\section{Data Availability}

RAC encourages data sharing but, in compliance with ethical principles, it does not demand the disclosure of any means of identifying research subjects, preserving the privacy of research subjects. The practice of open data is to enable the reproducibility of results, and to ensure the unrestricted transparency of the results of the published research, without requiring the identity of research subjects. 